\title{
O poema em prosa: a amorfia de uma modalidade lírica subutilizada no modernismo brasileiro
}

\section{RESUMO}

Átila Silva Arruda Teixeira atilalit@gmail.com

Universidade Federal de Goiás (UFG), Goiânia, Goiás, Brasil.
Nos textos críticos fundadores, a poesia lírica não é portadora de um estatuto que a iguala aos demais gêneros. Mesmo em períodos com maior normatização estética, não há como desconsiderar seu caráter proteiforme, ampliado desmesuradamente a partir da modernidade. Reverberando tal ampliação, surge o poema em prosa, modalidade da poesia lírica que ultrapassa a linha de delimitação que a distingue dos demais gêneros, encerrando já em seu nome um oxímoro que se reflete nas tentativas críticas de sistematização. Consolidado em outras literaturas, essa modalidade é subutilizada no cânone poético brasileiro. Esboçado na obra As noites da virgem, de 1868, de Vitorino Palhares, começa de forma consciente com Raul Pompéia em Canções sem metro, de 1881. Já no modernismo, é esparsamente utilizado. Conclui-se neste artigo que o poema em prosa ocupa uma posição periférica - inclusive atualmente - na lírica brasileira, devido a certo nefelibatismo que marcou a modalidade no nosso simbolismo, sendo substituído na função libertadora da lírica tradicional pelos versos livres.

PALAVRAS-ChAVE: Poesia lírica. Poema em prosa. Poema em prosa no Modernismo Brasileiro. 


\section{INTRODUÇÃO}

A noção de indivíduo é marcada pelo surgimento, consolidação e expansão do espaço urbano da pólis. Submetido as suas leis, o poeta e sua poesia lírica representam a busca por uma expressão particular sobre esse mundo. Originariamente ligado a um "eu", desde a Antiguidade, esse gênero é visto como uma composição biográfica na qual o próprio autor se valia dele para, aprioristicamente, expressar suas emoções e sentimentos pessoais. Esse fato, por seu turno, fazia o poema ser considerado como a voz do próprio poeta e era, sistematicamente, a única forma de conhecimento sobre a existência do mesmo, como ocorre com textos que são atribuídos a Álcman, íbico, Safo, Alceu dentre outros nomes da poesia lírica antiga. Essa inacessibilidade a outras referências para conhecer a vida dos poetas deste período, por outro lado, permite uma verdadeira criação de lendas sobre eles, e, acentuando esse romancear, há o fato de as composições que chegaram à contemporaneidade serem consideradas fragmentos, em sua imensa maioria. André Lardinois (1995) expõe essa situação em relação a Safo:

\footnotetext{
Uma edição erudita dos poemas de Safo, ou uma tradução não muito fantasiosa, contém apenas um poema completo, aproximadamente dez fragmentos substanciais, uma centena de citações breves de autores antigos e cerca de 50 peças e textos em papiro, que emergiram das areias do deserto egípcio. É por isso que é mais exato falar em fragmentos de Safo (apud RAGUSA, 2005, p.30).
}

Originário de uma tensão do indivíduo em relação a um novo estágio de desenvolvimento do seu mundo, a lírica passou cada vez mais a ser vista como um texto em que o poeta fala de si para o mundo por meio de determinados padrões sonoros, rítmicos e métricos. E mesmo o fato de esses padrões terem sido previa e plenamente difundidos entre os poetas, a relação entre a poesia lírica e a teoria normativo-descritiva sempre foi conturbada, havendo certa dificuldade para uma categorização do gênero lírico desde os primeiros textos críticos fundadores, inexistindo um estatuto próprio quando em contraposição à épica ou ao drama. $\mathrm{Na}$ Poética, exemplo mais emblemático de normatização desse período, Aristóteles (1992) faz rápidas menções aos ditirambos, mas tais referências não abarcam de maneira pormenorizada a lírica, destoando do procedimento adotado com os demais gêneros. Ao longo da obra, o Estagirita aponta várias minúcias concernentes à forma, como o fato de o drama ser escrito em versos jâmbicos, a épica em dátilos, a sátira e a farsa ligadas à representação das camadas populares, dentre outros aspectos; entretanto, sobre a lírica, há uma verdadeira lacuna, podendo tal característica ser atribuída a uma já existente variedade desse gênero literário, dificultando sua categorização.

Desse modo, a teoria que tentou se consolidar sistematizou a lírica como a versificação metrificada da expressão individual do poeta. Se, durante o Renascimento, a categorização da versificação retomou os elementos clássicos, como a elegia, a ode e as éclogas, cabe frisar que grande parte das melhores poesias líricas da época foi portadora de certa maleabilidade que não contemplava, integralmente, as normas e preceitos da teoria. $E$, no período 
romântico, a expressão individual esteve em consonância direta com a própria forma do poema:

No que concerne em geral à Forma, por meio da qual um tal conteúdo se torna obra de arte lírica, o indivíduo constitui aqui, em seu representar e perceber interior, o ponto central. O todo toma, por conseguinte, o seu começo no coração e no ânimo e, mais precisamente, na disposição e na situação particular do poeta, de modo que o Conteúdo e a conexão dos particulares, os quais o conteúdo se desenvolve, não permanecem sustentados objetivamente por si mesmos como conteúdo substancial ou pela aparição exterior como ocorrência individual fechada em si mesma, mas pelo sujeito (HEGEL, 2004, p. 159-160).

Esse caráter individualista da lírica foi tão fortemente colocado que ainda persiste em nossos dias. Exacerbando-se a subjetividade, "a concepção hegeliana de lírica seduziu e ainda seduz - talvez porque acene com a possibilidade de acesso do leitor aos sentimentos mais íntimos do poeta" (RAGUSA, 2005, p. 27). O sujeito é o ponto central da própria configuração lírica, sobrepondo-se a própria existência exterior do conteúdo abordado, fazendo com que o biografismo do poeta fosse a explicação estética do próprio poema.

Essa visão hegeliana, já a partir do século XIX, veio sistematicamente perdendo espaço devido a suas fragilidades, muitas vezes suplantando, paradoxalmente, o texto poético em si para explicá-lo. Criticava-se, sobretudo, a correspondência simplista entre a realidade do autor e a apresentada no poema, expondo uma clara crise no lirismo como expressão pessoal. Passou-se a considerar, em substituição a essa teoria romântica, as referências textuais internas do poema, buscando suas próprias qualidades, expandido e emancipando o gênero lírico a partir das potencialidades da linguagem. $O$ "eu" gerador da poesia lírica, portanto, se deslocou do poeta e passou a ser considerado o articulador dessas possibilidades de estruturação linguística dentro do poema.

Esse constructo crítico moderno de poesia lírica inicia-se no século XVIII, tomando corpo no XIX. Novalis, os irmãos Schlegel, Poe, Baudelaire, Rimbaud, Mallarmé, Lautréamont, dentre outros, erigiram uma maior valorização dos aspectos estruturantes da linguagem poética em detrimento a uma equalização simplória do poema como a realidade do poeta. A primazia pelas potencialidades do discurso literário dentro da poesia lírica pode ser percebida em inúmeros poemas e versos, como, por exemplo, em "Alquimia do verbo", de Rimbaud (1997, p. 50): "Foi primeiro um experimento. Escrevia silêncios, noites, anotava o inexprimível. Fixava vertigens". Maneira específica de um recorte do mundo, forjado pelo uso da linguagem, o viés moderno de compreensão da poesia lírica entrou em deliberada cisão com a concepção hegeliana, colocando em destaque a natureza do próprio discurso literário, seu encerramento em si mesmo e suas relações com a natureza dialógica da língua. Evidentemente, esse processo foi-se consolidando paulatinamente, adentrando o século XX e só nele se estabelecendo como principal diretriz no estudo desse gênero, de certa forma, cada vez mais proteiforme.

A linguagem poética encerra em si mesma por não ser portadora de uma finalidade prática, transgredindo seu uso sistematizado pelo cotidiano, visando não apenas uma nova forma de manifestação, mas também uma nova forma de 
significação. Para Maurice-Jean Lefebve (1980) a linguagem poética deve “[...] desligar o discurso do seu uso prático, em considerá-lo como um novo estado de linguagem em que o processo de significação contaria mais que o sentido ou a coisa significada" (LEFEBVE, 1980, p. 48). A plurissignificação, própria do discurso literário, tradicionalmente assentado nas figuras de linguagem, materializa-se por essa gratuidade de fechar-se em si mesma, mas também, ao libertar-se do caráter meramente utilitarista, estabelece uma ampliação das potencialidades de expressão da própria língua, uma vez que essa é precipuamente o grande arcabouço sociocultural de uma comunidade. Ainda segundo Lefebve: "[...] qualquer discurso com intenção literária é já figura em seu conjunto, pelo próprio facto de que, separado do seu referente prático, se constitui em objecto de linguagem e se apresenta na sua materialidade" (LEFEBVE, 1980, p. 46). Já Theodor Adorno (2012), no texto "Palestra sobre lírica e sociedade", afirma que esse pensamento social da obra de arte - a própria materialidade da mesma - não pode estreitar-se na inserção social da obra em si ou de seus autores, antes "tem de estabelecer, em vez disso, como o todo de uma sociedade, tomada como unidade em si mesma contraditória, aparece[r] na obra de arte; mostrar em que a obra de arte lhe obedece e em que a ultrapassa" (ADORNO, 2012, p. 67, grifo do autor). Essa materialidade, portanto, antes apreendida com uma voz de um "eu", passa a estar compreendida como um complexo jogo dialético entre um indivíduo e a sociedade, no qual o poeta não inventa a língua, mas é capaz de nela influir pela recepção.

Evidentemente, a relação entre o sujeito criador é mais proximal na lírica do que na narrativa, pois aquela organiza as potencialidades linguísticas internas ao poema, caracterizados nas relações entre sons, sentidos, ritmos e imagens através de uma expressão subjetiva, com um ponto de vista particular, valendo-se de uma maior liberdade por estar, mesmo que parcialmente, desvinculada das obrigações inerentes à narratividade. Entretanto, tratando-se de um discurso poético na configuração desse sujeito lírico, o vínculo direto com as contingências sociais é manifestado pela linguagem. Segundo Adorno (2012), isso ocorre,

Pois a própria linguagem é algo duplo. Através de suas configurações, a linguagem se molda inteiramente aos impulsos subjetivos; um pouco mais, e se poderia chegar a pensar que somente ela os faz amadurecer. Mas ela continua sendo, por outro lado, o meio dos conceitos, algo que estabelece uma inelutável referência ao universal e à sociedade (ADORNO, 2012, p. 74).

O duplo, referido por Adorno, está em consonância com o caráter individualcontextual presente nos atos comunicativos (BAKHTIN, 2003, p. 294) existentes no emprego das palavras. $O$ discurso poético, evidentemente, também é um contato da palavra com uma realidade concreta, realizada por um enunciado individual e, logo, também comunicativo; e mesmo que essa comunicação não seja realizada de forma denotativa, implicando, pelo contrário, uma polissemia precípua ao discurso literário, o emprego da linguagem não permite uma neutralidade em relação ao mundo e ao indivíduo. Nesse sentido, mesmo considerando a lírica a partir de uma estabilidade monológica do discurso do poeta, Bakhtin (2010) não deixa de considerar a ideia de uma linguagem única da poesia como utopia: 
repousam as condições e as exigências reais do estilo poético, que satisfaz a uma linguagem única, diretamente intencional, a partir de cujo ponto de vista as outras linguagens (a linguagem falada, a linguagem de negócios, a linguagem prosaica, etc.) são percebidas como objetivadas e em nada equivalentes a ele. A idéia de uma 'linguagem poética' particular expressa aquela mesma concepção ptolomaica de um mundo lingüístico estilizado (BAKTIN, 2010, p. 95).

Enquanto "filosofema utópico", logo irrealizável, o discurso poético não pode ser entendido como apartado da sociedade. Se antes as condições sociais detinham a primazia para explicar o fenômeno poético a partir de um biografismo do próprio poeta, a modernidade percebe essas contingências internas no próprio texto. E Baudelaire (2006), um dos principais pilares dessa forma de concepção artística, antecipou essa consonância entre o artista e seu tempo, refletido até no processo de criação da obra: "Há na vida ordinária, na metamorfose incessante das coisas exteriores, um movimento rápido que exige do artista idêntica velocidade de execução" (BAUDELAIRE, 2006, p. 853).

\section{O POEMA EM PROSA}

A Poesia lírica moderna caracteriza-se, sobretudo, pela transgressão da lógica. Não podendo mais ser entendida pelos critérios de uma normatização anterior ao poema, a poeticidade encontra-se nas tensões das possibilidades discursivas a partir de um viés particular do poeta, internalizando, como estrutura linguística, as contingências sociais. O mundo e a vida moderna, a partir das novas relações por eles estruturadas, impõem uma pesquisa profunda, afim de que o poeta possa captar, com uma visão pessoal, transcendente as essas mesmas contingências, a fugacidade desse instante. Para Baudelaire (2006), "a modernidade é o transitório, o efêmero, o contingente, é a metade da arte, sendo a outra metade o eterno e o imutável" (BAUDELAIRE, 2006, p. 859). Essa relação dissonante, presente em toda a lírica desse momento, leva o discurso poético da modernidade a acentuar a sua própria complexidade, marcando-se pela metalinguagem como ponto de partida para entender a problematização desse novo mundo, mesmo quando não explicitamente. Nas palavras de Adorno (2012):

A referência ao social não deve levar para fora da obra de arte, mas sim levar mais fundo para dentro dela. É isso o que se deve esperar, e até a mais simples reflexão caminha nesse sentido. Pois o teor de um poema não é a mera expressão de emoções e experiências individuais. Pelo contrário, estas só se tornam artísticas quando, justamente em virtude da especificação que adquirem ao ganhar forma estética, conquistam sua participação no universal (ADORNO, 2012, p. 66).

Logo, por universal temos as expressões que, apesar de particulares ao poeta, representam um todo coletivo. Nesse sentido, a "anormalidade" do discurso poético - para usar o termo cunhado por Jean Cohen (1978), no qual "a poesia não é a 'bela linguagem', mas uma linguagem que o poeta teve de inventar para dizer aquilo que não teria dito de outra forma" (COHEN, 1978, p. 132) - almeja, pela 
estética, atingir um sentido coletivo ligado a um universo comum. Para Alfredo Bosi (2000),

\begin{abstract}
As palavras concretas e as figuras têm por destino vincular estreitamente a fala poética a um preciso campo de experiências que o texto vai tematizando à proporção que avança. Como se, pela palavra, fosse possível ao poeta (e ao leitor) reconquistar de repente, a intuição da vida em si mesma. As figuras são procedimentos que visam a significar o processo dialético da existência que sempre desemboca no concreto. Mas elas só assumem pleno sentido quando integradas em um todo semântico que dá a cada uma delas a sua "verdade", isto é, a sua co-notação (BOSI, 2000, p. 136, grifo do autor).
\end{abstract}

O poema em prosa, por sua vez, representa um ponto crítico: a poesia lírica abandona seu último e mais significativo traço, o verso. Em uma carta para Arsène Houssaye, Baudelaire, o principal nome dos primórdios dessa modalidade, acaba por corroborar essa ligação da expressão particular com o todo universal, articulado por uma nova forma estética: "Quem dentre nós não sonhou, nos seus dias de ambição, com o milagre de uma prosa poética, musical sem ritmo e sem rima, flexível e desencontrada o bastante para adaptar-se aos movimentos líricos da alma, às ondulações do devaneio, aos sobressaltos da consciência?" (BAUDELAIRE, 1988, p. 17). Poema e prosa, não mais opostos excludentes, fundidos, rompem convenções em consonância com uma subjetividade problematizada por um mundo em profunda transformação.

Apesar do senso comum ainda considerar o verso como característica essencial da poesia, Aristóteles (1992), na Poética, mesmo tomando a poesia épica como exemplo, ressalta essa não vinculação: “Costuma-se dar esse nome [poeta] mesmo a quem publica matéria médica ou científica em versos, mas além da métrica, nada há de comum entre Homero e Empédocles; por isso, o certo seria chamar poeta ao primeiro e, ao segundo, antes naturalista do que poeta" (ARISTÓTELES, 1992, p. 20). O filósofo ainda consolida essa visão ao citar Heródoto: "Não é em metrificar ou não que diferem o historiador e o poeta; a obra de Heródoto podia ser metrificada; não seria menos uma história com o metro do que sem ele" (ARISTÓTELES, 1992, p. 28). Portanto, o verso em si não é condição sine qua non para a poesia.

Substancialmente, portanto, as qualidades do poema em prosa são as mesmas de um em versos, excetuando-se a métrica e a rima (mas persistindo a aliteração, a assonância, a repetição). Nele pode-se explorar não apenas os aspectos semânticos, rítmicos ou sonoros, igualando, de certa forma, a estrofe ao parágrafo, mas também os próprios conceitos clássicos da lírica: o poema como um todo orgânico, encerrado em si mesmo, breve, em que uma subjetividade organiza uma imagem poética. Independente da quantidade de linhas, o poema em prosa também visará à unidade, valendo-se da extrema liberdade de construção, podendo buscar na descrição, em fragmentos narrativos - e por vezes até pequenas histórias - ou ainda construindo verdadeiros aforismos, mas sempre de forma aberta, não totalmente dada ao leitor, a ser completada por ele, como sugere o curto poema de Mário Quintana (2012) intitulado "Construção": “... o dia exato alinha os seus cubos de vidro..." (QUINTANA, 2012, p. 149). 
Desdobrada da prosa poética no Pré-Romantismo e Romantismo alemães, as origens do poema em prosa estão ligadas a uma nova expressão poética, que, além de contemplar as novas estruturas do mundo moderno, sonda a si mesmo, expressando um novo estado de alma. Todorov (1980), ao julgar Heinrich Von Ofterdingen, de Novalis, como um romance poético, não centrado nas ações como normalmente seriam os romances, mas sim em impressões oníricas, além da abundante presença de poemas, ditos ou cantados, indica, ainda no final do século XVIII, uma tendência a intersimbiose entre a prosa e o poema e vice-versa.

Na França, Visconde de Parny, em Chansons Madécasses, de 1787, também já lidava com certo hibridismo, entre tom exótico e místico. Além disso, os próprios textos de Chateaubriand e de Rousseau eram portadores dessa aproximação entre poesia e prosa. Entretanto, Suzanne Bernard (1959, p. 34-47) apontou as traduções de baladas alemãs para a língua francesa como um instante de sensibilidade, liberdade e autenticidade poética até então não contempladas pela poesia francesa do século XVIII, além de traduções da Bíblia. Também devem ser considerado os questionamentos de Fénelon, em "Lettre à l'Académie" (1714), nos quais colocam em xeque a rigidez do verso clássico e o tradicionalismo da poesia produzida no século XVIII na França. De qualquer forma, seja pelo questionamento as estruturas fixas da poesia lírica de então, seja pelas traduções e até pelas falsas traduções, que alegavam a recuperação de textos poéticos distantes tanto espacial quanto temporalmente, nesse instante a rigidez dos gêneros foi discutida.

Entretanto, a obra inaugural de poemas em prosa é escrita apenas na década de 1830, e publicada postumamente em 1842: trata-se de Gaspard de la Nuit, de Aloysius Bertrand. Com um tom fantasmagórico, grotesco e com um caráter fantástico, Gaspard foi causador de polêmicas ${ }^{1}$. Mesmo nos manuscritos do próprio Bertrand, para se ter uma ideia, ele evitava a expressão "poemas em prosa", preferindo caracterizá-lo como um novo gênero de prosa (BERTRAND, 2000 , p. 900). Se a obra e seu autor foram taxados como "esquisitos", por outro lado, houve sim elogios efusivos e o maior deles, sem dúvida, coube a Baudelaire. Autor de Os pequenos poemas em prosa, escritos e publicados em revistas ao longo da década de 1850, publicado com livro apenas em 1869, a obra dialoga diretamente com Gaspard de la Nuit, segundo o próprio Baudelaire (1988):

Tenho uma pequena confissão a fazer-lhe. Foi folheando pela vigésima vez, no mínimo, o famoso Gaspard de la Nuit de Aloysius Bertrand (um livro conhecido por você, por mim e por alguns de nossos amigos não tem todo o direito de ser chamado famoso?), que me veio a idéia de tentar algo análogo, e de aplicar à descrição da vida moderna, ou melhor, de uma vida moderna e mais abstrata, o procedimento que ele havia aplicado à pintura da vida antiga, tão estranhamente pitoresca (BAUDELAIRE, 1988, p. 17).

Baudelaire, entretanto, não apenas produziu quadros-poemas com Bertrand, mas conseguiu dialogar esteticamente com a subjetividade inerente ao gênero lírico e com a sociedade a qual o próprio poeta estava inserido, confrontando suas contradições e ambiguidades. Refletindo sobre toda a produção do célebre poeta francês, afirma Adorno (2012): do mundo] europeu, não se contentou com os sofrimentos do 
indivíduo, mas escolheu como tema de sua acusação a própria modernidade, enquanto negação completa do lírico, extraindo dela suas faíscas poéticas, por força de uma linguagem heroicamente estilizada. Em Baudelaire já se anuncia um elemento de desespero, que se equilibra no cume do seu próprio caráter paradoxal (ADORNO, 2012, p. 75-76).

Esse registro da "dor do mundo" configura-se pelo amálgama da estética com o mundo em transformação. Esfacelou-se todo um passado em prol da industrialização e da urbanização, cabendo ao poema em particular, e as artes em geral, resistir à coisificação do próprio ser, não se integrando, em sua estrutura, a linguagem sistematizada do cotidiano. Afirmou Bosi (2010): "Essas formas estranhas pelas quais o poético sobrevive em um meio hostil ou surdo não constituem o ser da poesia, mas apenas o seu modo historicamente possível de existir no interior do processo capitalista" (BOSI, 2010, p. 165). A resistência, na obra de Baudelaire, se dá pela própria formulação do discurso poético, no qual o universal comum une-se a visão particular do poeta, o único que "goza deste incomparável privilégio de poder ser, a bel prazer, ele próprio e outrem" (BAUDELAIRE, 1988, p. 59).

Suzanne Bernard (1959), com a obra Le poème en prose de Baudelaire jusqu'à nos jours, é a maior autoridade sobre o poema em prosa. Com uma obra de fôlego, Bernard intencionou não apenas suprir uma ausência crítica sobre essa modalidade, mas também tentou categorizá-la. Se no primeiro propósito ela foi extremamente feliz, sendo seu estudo uma referência obrigatória sobre o tema, quanto ao segundo não se pode afirmar que houve o mesmo sucesso, justamente por querer sistematizar uma modalidade marcada por uma amorfia, apesar das considerações pertinentes que ela teceu. Modalidade recente, originado da poesia lírica moderna, o poema em prosa tem muito mais questões em aberto, quanto a sua estrutura, do que respostas ${ }^{2}$. Essa dificuldade de síntese crítica - que permeia toda a lírica - parece acentuar-se quando se trata desse tipo de poema. Mesmo reconhecendo essas particularidades - Bernard começa a obra com uma citação de Guy Lavaud, "O poema em prosa não está definido, ele existe" ${ }^{3}$ (BERNARD, 1959, p. 11) - ela constrói sua teoria sobre os fundamentos da totalidade de efeito, concentração, gratuidade e intensidade. Nas palavras da própria autora,

Totalidade de efeito, concentração, gratuidade, intensidade: expressões que ao mesmo tempo confirmam a ideia de que o poema é um mundo fechado, suficiente em si mesmo, e ao mesmo tempo um tipo de bloco irradiante, carregado, sob um volume débil, de uma infinidade de sugestões, e capaz de abalar nosso ser em profundidade. Esse universo, como em toda obra de arte, é um universo de relações ${ }^{4}$ (BERNARD, 1959, p. 439-440).

Fica claro uma inter-relação entre todos esses fundamentos. Falar de totalidade de efeito é também abranger a concentração e intensidade, uma vez que, o poema encerraria em si uma brevidade sintética tensa e/ou contraditória, se valendo como poema por não estabelecer uma continuidade narrativa com outros textos, apesar de, evidentemente, poder conter em si um fragmento de narração. Se há essa concentração e intensidade, por sua vez, o poema em prosa é dotado de um tom elíptico: não há um encadeamento narrativo acabado em si, mas sim uma imagem que contém toda uma tensão poética que deve ser construída simbolicamente em conjunto com o leitor. 
Já em relação à gratuidade, a definição de Bernard é mais precisa por pressupor não apenas a construção estética em si, mas por diferenciá-la dos gêneros narrativos. Buscando o atemporal, um instante de alta complexidade, o poema em prosa seria portador de uma presentificação eterna, uma vez que não há nesse flagrante uma noção pretérita nem futura em relação a ele. Essa presentificação, por sua vez, seria construída sobre os aspectos figurativos e estilísticos da linguagem, sobretudo a metáfora e as aliterações, assonâncias, repetições e bruscos cortes sintáticos. Analisando um dos poemas em prosa mais aclamado da literatura brasileira, pode-se confirmar as assertivas de Suzanne Bernard: trata-se de "O grande desastre aéreo de ontem", de Jorge de Lima (2008):

Para Cândido Portinari

Vejo sangue no ar, vejo o piloto que levava uma flor para a noiva, abraçado com a hélice. $\mathrm{E}$ o violinista em que a morte acentuou a palidez, despenhar-se com sua cabeleira negra e seu estradivárius. Há mãos e pernas de dançarinas arremessadas na explosão. Corpos irreconhecíveis identificados pelo Grande Reconhecedor. Vejo sangue no ar, vejo chuva de sangue caindo nas nuvens batizadas pelo sangue dos poetas mártires. Vejo a nadadora belíssima, no seu último salto de banhista, mais rápida porque vem sem vida. Vejo três meninas caindo rápidas, enfunadas, como se dançassem ainda. E vejo a louca abraçada ao ramalhete de rosas que ela pensou ser o pára-quedas, e a prima-dona com a longa cauda de lantejoulas riscando o céu como um cometa. E o sino que ia para uma capela do oeste, vir dobrando finados pelos pobres mortos. Presumo que a moça adormecida na cabine ainda vem dormindo, tão tranqüila e cega! ó amigos, o paralítico vem com extrema rapidez, vem como uma estrela cadente, vem com as pernas do vento. Chove sangue sobre as nuvens de Deus. E há poetas míopes que pensam que é o arrebol (LIMA, 2008, p. 370).

O poema é condensado em apenas um parágrafo, mas estruturalmente pode ser dividido em duas partes: a primeira terminada na sentença "Corpos irreconhecíveis identificados pelo Grande Reconhecedor" e, começando logo depois, a segunda, na qual se apresenta sumariamente os elementos constitutivos da imagem e a sua presentificação e subjetividade explicitadas pela desinência verbal em "vejo". A segunda parte começa repetindo a sentença que inicia o poema, como a reafirmar a cena sui generis que estava a ser observada. Se na primeira parte os elementos foram apresentados de forma introdutória, na segunda eles são mais detidamente vistos, aflorando as suas contradições: o piloto, a levar flores para noiva, abraçado à hélice, de fato sua última companheira; o violinista a cair com seu estradivárius, objeto de tamanha reputação, mas totalmente inútil para aquele momento; a nadadora a fazer seu último salto, agora mais veloz; três meninas, despencando para a morte (isso se de fato não estivessem mortas) como se dançassem; a louca, a única que parece entender a gravidade da situação, fazendo de um ramalhete, paraquedas; e uma mulher que atravessa como um cometa. A contradição é acentuada pelas imagens do sino, que vem badalando, como que a anunciar os mortos; por a moça vir tranquila e cega, ainda a dormir e, principalmente, pelo paralítico vir "como uma estrela cadente", "com as pernas do vento". 
O próprio título do poema acentua essas contradições. Apesar de trágicos e lamentáveis, os desastres aéreos banalizaram-se cada vez mais em nosso cotidiano, e, da forma como foi colocada, sobretudo pelo termo "ontem", há a ideia de periodicidade de acidentes, assim, assemelhando-se a leitura de uma manchete de jornal, denotativa e referencial. Essa ideia é desfeita logo na primeira sentença, marcada por um "eu" que acaba por associar o sangue das vítimas a uma verdadeira "chuva". E neste instante da explosão, da queda dos corpos e da chuva de sangue, se constrói a imagem do poema, como um verdadeiro quadro marcado por um clarão e por essa anormal precipitação. Essa imagem, por seu turno, justifica a dedicatória a um dos principais pintores da história do Brasil. O leitor, tal qual nos quadros de Cândido Portinari, assombra-se com o jogo pictórico de Jorge de Lima, interseccionados pela tragédia.

Deve-se frisar ainda a presença da religiosidade, pelo epíteto "Grande Reconhecedor", depois o próprio uso da palavra "Deus", encerrando a penúltima sentença do poema, além de várias referências diretas, como "nuvens batizadas pelo sangue dos poetas mártires" e o próprio sino que vem a dobrar pelos mortos, como em finados. Essa presença dentro de um sistema marcado pela contradição converge diretamente ao clímax - a última sentença -, ou seja, a incapacidade de apreensão das coisas como são em seu aspecto transcendental, concernente só a Deus e aos poetas não-míopes, capazes de buscar a vida em seu aspecto ontológico.

Contraposto aos fundamentos de Suzanne Bernard, o poema de Jorge de Lima é muito bem categorizado. Há um efeito de totalidade, fechado em si mesmo, que apresenta uma imagem presentificada elipticamente, não havendo uma progressão narrativa - há a explosão e a queda dos corpos e de sangue, a ponto de considerá-lo uma "chuva". Além disso, a contradição está presente em praticamente em todas as sentenças, valendo-se, principalmente, das alterações nas capacidades físicas e emocionais das vítimas, como o fato já mencionado de o paralítico vir "com as pernas do vento", devido à explosão. Por fim, as estratégias estéticas adotadas, tais quais o jogo semântico contraditório, a diferença entre o acontecimento e aquilo que os poetas míopes enxergam, além da repetição de termos - "vejo" aparece sete vezes ao longo do poema, enquanto "vem", cinco, reforçando a imagem anormal do que se vê, além de cadenciar o ritmo do próprio poema - conferem ao discurso poético uma gratuidade a ser entendida como a primazia estética em relação ao utilitarismo dos demais discursos do cotidiano.

Isso posto, infere-se que esses fundamentos são conceituados de forma muito ampla, valendo, inclusive, para os poemas em verso livre. As infinidades de estratégias que o poema em prosa pode dispor pertencem não apenas a essa modalidade, mas a toda lírica contemporânea. Não se nega aqui, portanto, a validade desses fundamentos, sendo todos caros a lírica moderna; o que se relativiza e a restrição deles ao poema em prosa, que deve ser, no entendimento aqui construído, refutada.

Outro ponto complexo de Bernard (1959) está na consideração do poema em prosa como um gênero poético distinto, apartado tanto do poema, devido a sua liberdade anárquica, quanto da prosa, por não almejar à narratividade. A ideia do paradoxo, presente no próprio nome, se desfaz, sendo, portanto, um terceiro viés literário. Disse a autora, 
o poema em prosa perfaz um gênero distinto: não é um meiocaminho híbrido entre prosa e verso, mas um gênero de poesia particular que se serve da prosa ritmada com fins estritamente poéticos, impondo-lhe simultaneamente uma estrutura e uma organização gerais, cujas leis devemos descobrir: leis não apenas formais, mas profundas e orgânicas, como em todo gênero artístico real e verdadeiro ${ }^{5}$ (BERNARD, 1959, p. 434).

Considerar o poema em prosa como um gênero distinto obrigaria a uma revisão do próprio gênero lírico, considerando-o muito mais como um domínio do que um gênero propriamente dito. Apesar de extremamente pertinente, tal proposta representaria uma desconsideração de elementos comuns as mais diversas modalidades e a criação infinita de novos gêneros cada vez que um poeta se valesse de uma nova estratégia discursiva, particularizando indefinidamente o discurso poético, produzindo, por exemplo, o "gênero versos brancos", o "gênero versos livres", o "gênero poesia concreta", o "gênero poesia de cordel" e assim por diante.

Estabelecer uma estrutura do poema em prosa, ignorando suas características anárquicas, é desconsiderar que essa modalidade coloca em xeque a própria noção de lírica dentro do viés tradicional. Há, evidentemente, elementos recorrentes, como a brevidade, como a intensidade em busca de uma síntese do próprio discurso poético - dizer o máximo a partir do mínimo -, como uma subjetividade marcada e uma relação mais proximal entre o sujeito do poema e o poeta, além da resistência ao transitório da modernidade pelo fluir das imagens poéticas, concêntricas, perquirindo a si mesmo em meio ao próprio caos da linguagem. Por outro lado, como essas características têm um caráter amplo, a organização das potencialidades desse discurso no interior do poema dependerá de uma expressão particular. Nesse sentido, quanto mais levantar-se diferentes poemas em prosa, mais inovações e similitudes serão observadas. É o que fez Tzvetan Todorov (1980). Em diálogo direto com a pesquisa de Bernard, o crítico acrescenta os critérios da apresentação e da representação para se pensar o poema em prosa, propondo uma explicação mais pormenorizada dessa modalidade:

\begin{tabular}{|l|l|l|}
\hline & VERSO & PROSA \\
\hline Apresentação & Poesia & Poema em prosa \\
\hline Representação & $\begin{array}{l}\text { Epopeia, narração e } \\
\text { descrição, versificadas }\end{array}$ & Fiç̧ão (romance, conto) \\
\hline
\end{tabular}

De simples leitura, o gráfico centra-se na mimese. Se o discurso for concatenado sem o caráter mimético, estaria no âmbito da apresentação, o contrário, na representação, teoricamente apoiado nas pesquisas de Étienne Souriau. O filósofo francês distingue a apresentação da representação da seguinte forma: "Nas artes apresentativas, obra e objeto se confundem. A obra representativa suscita, por assim dizer, ao lado e fora dela" (apud TODOROV, 1980, p.121). O crítico, entretanto, não deixa de perceber certa deficiência nesses critérios e a partir de Illuminations, de Rimbaud e aponta o que ele chama de "frases indeterminadas" (TODOROV, 1980, p. 123) do jovem poeta, alegando que "cada palavra pode evocar uma representação, mas seu conjunto não constitui um todo e nos incita pois a nos limitarmos às palavras" (TODOROV, 1980, p. 123). 
Ciente que não se pode dicotomizar apresentação/representação, Todorov acrescenta:

A oposição entre apresentação e representação pela linguagem não se situa entre duas classes de enunciados, mas entre duas categorias. A linguagem pode ser transparente ou opaca, transitiva ou intransitiva; mais não são estes senão pólos extremos, e os enunciados concretos se situam, por assim dizer, sempre em algum lugar entre ambos, estando apenas mais próximos de uma ou de outra extremidade (TODOROV, 1980, p. 124).

Condensando bem a noção de gêneros literários, o quadro consegue colocar a "anarquia libertadora" de Bernard no âmbito da apresentação pela inverossimilhança. Questiona-se, entretanto, se realmente representação e poesia (lírica) são inconciliáveis, persistindo, portanto, a tentativa de normatização de uma modalidade proteiforme.

Entretanto, as análises de Bernard e a de Todorov possuem vários pontos de contato, e elas podem situar a essência do poema em prosa. A mais pertinente é o dualismo dessa modalidade. As contradições entre verso $x$ sentença, brevidade $x$ fragmentos de narratividade, efemeridade do mundo moderno $x$ atemporalidade do "eu", podem começar a ser compreendidas como a própria força motriz do poema em prosa, visando à superação dos limites da lírica contemporânea, sempre em direção à liberdade da expressão particular, apenas mediada pelo caráter dialógico da própria linguagem. Apesar de ter como objetivo a lírica moderna em geral, as palavras de Adorno (2012) são cruciais para entender essa conciliação de contrários dentro do poema em prosa, que pela característica social do discurso, expressa uma subjetividade que exempla uma relação histórica de um indivíduo com sua sociedade:

Costuma-se dizer que um poema lírico perfeito tem de possuir totalidade ou universalidade, tem de oferecer, em sua limitação, o todo; em sua finitude, o infinito. Se isso for algo mais que um lugarcomum daquela estética que tem sempre à mão, como panacéia universal, o conceito do simbólico, então isso mostra que em cada poema lírico devem ser encontrados, no medium do espírito subjetivo que se volta sobre si mesmo, os sedimentos da relação histórica do sujeito com a objetividade, do indivíduo com a sociedade. Esse processo de sedimentação será tanto mais perfeito quanto menos a composição lírica tematizar a relação entre o eu e a sociedade, quanto mais involuntariamente essa relação for cristalizada, a partir de si mesma, no poema (ADORNO, 2012, p. 72, grifos do autor).

\section{O POEMA EM PROSA NO BRASIL: UMA SUBUTILIZAÇÃO}

Autor da obra Encontros necessários, inteiramente composta por poemas em prosa, Marcello Rollemberg (1997-1998) publicou um artigo, pelo título, provocador: "Onde está a poesia em prosa no Brasil?". Considerando a produção poética brasileira uma das mais profícuas do mundo, tanto em quantidade, como, principalmente, em qualidade, Rollemberg afirmou: nomes como João Cabral de Melo Neto, Carlos Drummond de 
Andrade, Augusto e Haroldo de Campos, Ferreira Gullar, Ana Cristina César e Alexei Bueno, entre outros. A lista é grande e certamente ficará incompleta, por mais que se tente elencar nomes e mais nomes que produziram e ainda produzem bons poemas no país. Mas, e a poesia em prosa [...] onde está? A resposta é simples: não está (ROLLEMBERG, 1997-1998, p. 180).

Marcello Rollemberg não chega a levantar uma hipótese para essa ausência, limitando-se a convocar possíveis poetas-leitores a produzir este gênero: "Essa lacuna ainda está aberta e precisa - mais que isso, merece - ser preenchida. A produção poética brasileira é muito rica, mas não pode se dar ao luxo de desprezar um estilo que alia, em um mesmo texto, beleza, sensibilidade e inteligência em doses industriais" (ROLLEMBERG, 1997-1998, p. 181). Com apelo ou não, fato é que Rollemberg tem razão. Apenas a título de exemplo, a seleção "Os cem melhores poemas brasileiros do século" abrangendo todo os novecentos, organizada por Ítalo Moriconi, possui apenas $u^{6}{ }^{6}$ poema nessa modalidade. As razões para essa subutilização podem estar em fatores históricos.

Consolidado na França, durante o século XIX, Baudelaire e Rimbaud são os grandes responsáveis pela propagação dessa modalidade ainda nos oitocentos. Mas é sobretudo com a obra Pequenos poemas em prosa, livro póstumo do primeiro, publicado em 1869, que o poema em prosa atinge outras literaturas, criando-se um verdadeiro culto ao seu autor e a uma produção dessa modalidade. Nesse primeiro instante, na América hispânica, destaca-se Rubén Darío e Julián del Casal; em Portugal, João Barreira; no Brasil, Raul Pompéia e Cruz e Sousa.

A primeira obra brasileira dentro dessa modalidade foi As noites da virgem, de Vitoriano Palhares, publicada em Paris no ano de 1868. De pequena qualidade estética, considerada muito mais pelo aspecto histórico, seus problemas esbarram nas imensas descrições românticas, em uma lassa linguagem literária apoiada em chavões e de pequena figurativização.

Qualidade bem superior é encontrada em Canções sem metro, de Raul Pompéia. Escritas a partir de 1881, publicadas esparsamente em revistas, apenas foram compiladas em livro em 1900. Na História Concisa da Literatura Brasileira, Bosi (2004) fez as seguintes afirmações sobre a obra: "ensaio estetizante de prosa poética, que resultou menos rico do que a linguagem do Ateneu, mas vale como prova de um extremo cuidado no traço das formas" (BOSI, 2004, p. 184). Reconhece-se uma dedicação comprometida com a modalidade, expressa até pelo título da obra, mas sua apreensão crítica continua aquém do esperado. Apresentando um contato com a obra Gaspard de la Nuit, de Aloysius Bertrand, pelo aspecto fantasmagórico, tendo também Baudelaire como uma espécie de orientador e, ao mesmo tempo, com a mesura da composição de um quadro parnasiano, Canções sem metro valem pela sua qualidade estética e pela ligação as concepções baudelarianas, como no poema "A noute":

... le ciel se ferme lentement com-

me une grande alcove, et l'homme

impatient se chane em bête fauve. 
Chamamos treva à noute. A noute vem do Oriente como a luz. Adiante, voam-lhe os gênios da sombra, distribuindo estrelas e pirilampos. A noute, soberana, desce. Por estranha magia revelam-se os fantasmas de súbito.

Saem as paixões más e obscenas; a hipocrisia descasca-se e aparece; levantam-se no escuro as vesgas traições, crispando os punhos ao cabo dos punhais; à sombra do bosque e nas ruas êrmas, a alma perversa e a alma bestial encontram-se como amantes apalavrados; tresanda o miasma da orgia e da maldade - suja o ambiente; cada nova lâmpada que se acende, cada lâmpada que expira é um olhar tôrvo ou um olhar lúbrico; familiares e insolentes, dão-se as mãos o vício e o crime - dois bêbedos.

Longe daí, a gemedora maternidade elabora a certeza das orgias vindouras.

E a escuridão, de pudor, cerra-se, mais intensa e mais negra.

Chamamos treva à noute - a noute que nos revela a subnatureza dos homens e o espetáculo incomparável das estrêlas (POMPÉlA apud PLACER, 1962, p. 34-35).

"A noute" é um representativo poema em prosa de Pompéia. Conhecido sobremaneira por $O$ Ateneu, a crítica literária brasileira julgou o poeta e sua obra como "figura singular, inclassificável, que se refugiou num cultismo fora de época" (SODRÉ, 2002, p. 511) ou ainda um "decorativismo parnasiano" (MERQUIOR, 1996, p. 258). A influência de Baudelaire é pertinente, seja pela temática e pela própria sondagem de um "eu" profundo. Por outro lado, não se pode desconsiderar o apuro formal - Canções sem metro foram escritas e reescritas por quase 20 anos, publicadas apenas postumamente. Esse apuro levou alguns críticos a apontar na obra uma índole parnasiana; outros, por sua vez, pelas imagens criadas, o enquadraram no simbolismo. Essa contradição crítica revela, na verdade, a riqueza da obra em si e a junção de opostos empreendidos no próprio poema: a noite releva nossa subnatureza, mas ela também nos dá as estrelas.

E se os poemas em prosa de Raul Pompéia são relegados ao esquecimento, mesmo sendo uma obra de valor estético interessante, a crítica é muito mais incisiva com Cruz e Sousa. Bosi (2004) citou Brito Broca para construir sua crítica sobre os poemas em prosa do autor de Evocações. Afirmou Broca:

as más heranças da prosa encontraram terreno fértil e propício para desenvolver-se entre nós. Desde o começo do século que se implantou em nossas revistas literárias e mundanas, com vinhetas e ilustrações, um gênero de crônica meio poemática, espécie de divagação fantasista sobre motivos abstratos, mero jogo de palavras, em que se exercitavam a habilidade e o engenho verbal dos autores. Era assimilação do pior Simbolismo pelo pior Parnasianismo, e o tipo perfeito desse mal da literatice, que se tornou um dos principais alvos dos modernistas (BROCA apud BOSI, 2004, p. 293, grifos meus). 
Antônio Donizeti Pires (2000) levantou uma consideração importante, contrária a uma depreciação da obra em prosa de Cruz e Sousa. Para ele "mais que narrativa falhada, os poemas em prosa de Cruz e Sousa [...] também podem ser vistos como complementares, em mais de um sentido, à sua poesia em versos" (PIRES, 2000, p. 170). Não se pode negar, entretanto, que os poemas em prosa do autor de Missal, de uma forma geral, ficaram aquém do em versos; mesmo assim, não cabe a Cruz e Sousa uma crítica tão severa, a ponto de considerar essas produções como "um mero jogo de palavras". A questão parece mais complexa e deve ser considerada no conjunto das obras que se valiam dessa modalidade lírica na época. Havia sim um exagero ligado a um modismo no uso do poema em prosa, acompanhado, naturalmente, de uma superficialidade e inconsistência estética, durante o simbolismo. E esse uso excessivo, aliado a não decantação dos textos de Baudelaire, Rimbaud e outros importantes poetas dessa modalidade, pintando-se imagens não organicamente integradas aos próprios poemas, tornando-os cada vez mais nebulosos, justifica um postura crítica incisiva e o afastamento dos próprios modernistas de uma modalidade que mais ornava que comunicava, em destoante relação com os próprios ideais dos protagonistas da Semana de Arte Moderna de 1922.

\section{CONCLUSÃO}

Talvez a modalidade que mais revele o caráter amórfico da poesia lírica moderna, o poema em prosa não tem ainda seu estatuto totalmente inventariado. Não por ausência de estudos de fôlego sobre essa questão, mas sim pela transgressão existente em unir dois opostos, a sentença e o verso, em uma "anarquia libertadora", nas palavras de Suzanne Bernard (1959), multiplicando indefinidamente as possibilidades de configuração dessa modalidade. Essa tentativa de conciliar contrários, almejando à narratividade e à brevidade, à gratuidade dos versos e à cursividade da prosa estão vinculados à simultaneidade do próprio mundo moderno. Dessa forma, a apreensão desse caráter social por um "eu" e a expressão particular dessa multiplicidade em um discurso poético, irmana pela linguagem todos os que veem na lírica uma possibilidade de resistir a essa efemeridade reificadora da modernidade. Nas palavras de Adorno (2012),

\footnotetext{
Uma corrente subterrânea coletiva é o fundamento de toda lírica individual. Se esta visa efetivamente o todo e não meramente uma parte do privilégio, refinamento e delicadeza daquele que pode se dar ao luxo de ser delicado, então a substancialidade da lírica individual deriva essencialmente de sua participação nessa corrente subterrânea coletiva, pois somente ela faz da linguagem o meio em que o sujeito se torna mais do que apenas sujeito (ADORNO, 2012, p. 77).
}

Por outro lado, essa capacidade de resistência como também o fim do servilismo à normatização da lírica tradicional não residem apenas no poema em prosa. Sérgio Milliet (1955), em uma conferência intitulada "O poema em prosa", aponta as razões para que essa modalidade fosse fundamental para a modernidade lírica na França, mas não no Brasil: 
emoções e os sentimentos complexos do homem moderno, de um novo instrumento, mais rico de possibilidades. Queria-o Baudelaire "sem rima nem ritmo", elástico, maleável de fácil manuseio. Acontece que a poesia se libertou do metro e da rima, permitiu-se todas as licenças. E o poema prosa perdeu suas razões de ser. Não passa hoje de uma simples e arbitrária denominação para a prosa poética ou e um arranjo tipográfico para o verso livre (MILLIET, 1955, p. 22).

Apesar de questionável, pois desconsidera a existência da modalidade em si, a afirmação de Milliet tem a sua razão de ser. Mais de dois séculos depois do seu surgimento, o poema em prosa não assumiu a posição central na poesia lírica moderna de nenhuma literatura ocidental. Há, evidentemente, cada vez mais uma intersimbiose entre a prosa e o poema, como já prenunciava Novalis. A prosa está cada vez mais lírica, assim como o poema está cada vez mais prosaico. Essa questão, entretanto, não reside apenas na lírica, mas sim na própria crise dos gêneros literários advinda com a modernidade, sobretudo com a ascensão do romance. Não há sustentação em uma postura crítica que defenda as fronteiras discursivas em um mundo cada vez mais sem fronteiras. Responsável por manter a mediação entre a lírica e a sociedade, assegura-se a comunicabilidade quando "o sujeito, alcançando a expressão feliz, chega a uma sintonia com a própria linguagem, seguindo o caminho que ela mesma gostaria de seguir" (ADORNO, 2012, p. 74).

Para Afrânio Coutinho (apud PLACER, 1962, p. 06), o poema em prosa se mostraria "um quadro seguro da evolução entre nós, de tão promissor gênero literário". Apesar da afirmação do crítico ainda não ter se concretizado, uma vez que a nossa ruptura com a lírica tradicional deu-se pelo verso livre e pela poesia concreta, é plausível que haja uma maior produção qualitativa desse tipo de poema. Nomes como Claúdio Willer, Zulmira Tavares Ribeiro e Marcello Rollemberg sistematicamente produzem e publicam nessa modalidade.

Por fim, deve-se entender a contenção modernista na produção do poema em prosa, quantitativamente pequena nos principais poetas modernistas, como uma forma de recusar modismos e buscar uma poesia lírica diferente do tom nefelibato que o poema em prosa tinha até então. Essa contenção, por outro lado, foi responsável pela criação de poemas em prosa já assimilados por nossa tradição literária, como os de Manuel Bandeira, Carlos Drummond de Andrade, Xavier Placer, Oswaldino Marques e as obras Sapato Florido (1948), de Mário Quintana e Poemas em prosa (1955), de Aníbal Machado. 


\title{
The poem in prose: the formless mode of a way of lyric poetry underutilized in Brazilian Modernism
}

\begin{abstract}
In the founding critical texts, lyric poetry is not a carrier of a statute that equates to the other genres. Even in periods with greater aesthetic norms, there is no way to disregard certain protean character of the same, magnified enormously from modernity. Reverberating such an extension, the prose poem, a form of lyric poetry that goes beyond the demarcation line that distinguishes it from other genres, already in its name ending an oxymoron that is reflected in the critical attempts to systematize arises. Consolidated in other literatures, this modality is underutilized in the Brazilian poetic canon. The work outlined in the Noites da virgem, book publicated by Vitorino Palhares in 1868, consciously begins with Raul Pompéia in the Canções sem metro (1881). Already on the modernism, it is sparsely used. Even so, this paper concludes that the prose poem occupies a peripheral position - even today - in Brazilian poetry because a fog tone that marked the modality in our symbolism, being replaced in the liberating function of the traditional lyric by free verse.
\end{abstract}

KEYWORDS: Lyric Poetry. Prose poem. Prose poem in Brazilian Modernism. 


\section{NOTAS}

1 Como sugestão de leitura sobre a recepção da obra de Bertrand, aconselha-se o artigo de Lenon Rogério de Melo Franco, intitulado "A recepção maldita de Gaspard de la Nuit, de Aloysius Bertrand, nos séculos XIX e XX". Disponível em: $<$ http://revistas.iel.unicamp.br/index.php/seta/article/view/404/343>. Acesso em 10 de dez. 2016.

2 Não há consenso, por exemplo, se trechos de romances tomados isoladamente seriam ou não poemas em prosa. Quanto à consideração dessa modalidade enquanto gênero, o crítico americano Jonathan Holder (1991) chega a defender que o poema em prosa é, na verdade, um antigênero.

3 "Le poème en prose ne se définit pas, il existe". Todas as traduções neste artigo são de minha autoria.

4 "Totalité d'effet, concentration, gratuité, intensité: autant d'expressions qui nous confirment dans l'idée que le poème est un monde clos, fermé sur soi, se suffi sant à soi-même, et en même temps une sorte de bloc irradiant, chargé, sous un faible volume, d'une infinité de suggestions, et capable d'ébranler notre être en profondeur. Cet univers, comme toute oeuvre d'art, est un univers de relations".

5 "le poème en prose est bien un genre distinct: non pas un hybride à mi-chemin entre prose et vers, mais un genre de poésie particulier, qui si sert de la prose rythmée à des fins strictement poétiques, et lui impose pour cela une structure et une organisation d'ensemble, dont il nous reste à découvrir les lois: lois non seulement formelles, ais profondes, organiques, comme dans tout genre artistique véritable".

6 Trata-se de "Carta de Paris", de Ana Cristina Cesar.

\section{REFERÊNCIAS}

ADORNO, Theodor. Palestra sobre lírica e sociedade. Notas de Literatura I. Trad. e apr. Jorge de Almeida. 2 ed. São Paulo: Duas cidades; Ed.34, 2012. p. 65-90.

ARISTÓTELES, HORÁCIO, LONGINO. A poética clássica. Introdução por Roberto de Oliveira Brandão, tradução direta do grego e do latim por Jaime Bruna. São Paulo: Cultrix, 1992.

BAKHTIN, Mikhail. Estética da criação verbal. Trad. Paulo Bezerra. 4. ed. São Paulo: Martins Fontes, 2003.

Questões de literatura e estética (a teoria do romance). Trad. russo por Aurora Bernardini, José Pereira Junior, Augusto Góes Junior, Helena Nazário e Homero F. de Andrade. 6 ed. São Paulo: Hucitec; Editora da UNESP, 2010. 
BAUDELAIRE, Charles. "O pintor da vida moderna". Poesia e prosa. Trad. Ivan Junqueira. Rio de Janeiro: Nova Aguilar, 2006. p.851-881

Petits poems en prose; Pequenos poemas em prosa. Trad Dorothée de Bruchard. Florianopólis: Ed. UFSC, Aliança Francesa, 1988.

BERNARD, Suzanne. Le poème en prose: de Baudelaire jusqu'à nos jours. Paris: Nizet, 1959.

BERTRAND, A. Oeuvres complètes. Édition par Helen Hart Poggenburg. Paris: H. Champion, 2000.

BOSI, Alfredo. História concisa da literatura brasileira. 42. ed. São Paulo: Cultrix, 2004.

O ser e o tempo na poesia. 8 ed. rev. amp. São Paulo: Companhia das Letras, 2010.

COHEN, Jean. Estrutura da linguagem poética. 2.ed. Trad. Alvaro Lorencini e Anne Arnichand. São Paulo: Cultrix, 1978.

HEGEL, G.W.F.. Cursos de estética. v.IV. Trad. Marco Aurélio e Oliver Tolle. São Paulo: Edusp, 2004. (Clássicos; 26)

LEFEBVE, Maurice-Jean. Estrutura do discurso da poesia e da narrativa. 2 ed. Trad.José Carlos Seabra Pereira. Coimbra: Almedina, 1980.

LIMA, Jorge de. Poesia completa. Rio de Janeiro: Nova Fronteira, 2008.

MERQUIOR, José Guilherme. De Anchieta a Euclides - breve história da literatura brasileira. 3. ed. Rio de Janeiro: Topbooks, 1996.

MILLIET, Sérgio. "O poema em prosa". In: Três conferências. São Paulo: Ministério de Educação e Cultura, 1956.

QUINTANA, Mário. Canções seguido de Sapato florido e a Rua dos Cataventos. Rio de Janeiro: Objetiva, 2012. 
PIRES, Antonio Donizeti. Pela volúpia do vago: algumas reflexões sobre o poema em prosa no Brasil. Temporis (Ação): revista da Unidade Universitária Cora Coralina/UEG.v.1, n.4, (2000). Goiàs: Kelps, 2000. p.155-180.

PLACER, Xavier. O poema em prosa. Rio de Janeiro: Ministério de Educação e. Cultura; Serviço de Documentação, 1962.

TODOROV, Tzvetan. Os gêneros do discurso. Trad. Elisa Angotti Kossovitch, São Paulo: Martins Fontes, 1980.

RAGUSA, Giuliana. Fragmentos de uma deusa: representação de Afrodite na lírica de Safo. Campinas: Ed. Unicamp, 2005. p.23-53.

RIMBAUD, Arthur. Uma temporada no Inferno. Trad. Paulo Hecker Filho. Porto Alegre: L\&PM, 1997.

ROLLEMBERG, Marcello. Onde está a poesia em prosa no Brasil? Disponível em: <http://www.usp.br/revistausp/36/18-marcello.pdf>. Acesso em 17 de dez. 2013.

SODRÉ, Nelson Werneck. História da Literatura Brasileira. 10. ed. Rio de Janeiro: Graphia, 2002.

Recebido: 15 out. 2015

Aprovado: 29 fev. 2016

DOI: $10.3895 /$ rl.v12n25.3238

Como citar: TEIXEIRA, A. S. A. O poema em prosa: a amorfia de uma modalidade lírica subutilizada no Modernismo

brasileiro. R. Letras, Curitiba, v. 18, n. 23, p. 131-150, jul./dez. 2016. Disponível em:

<https://periodicos.utfpr.edu.br/rl>. Acesso em: XXX.

Direito autoral: Este artigo está licenciado sob os termos da Licença Creative Commons-Atribuição 4.0 Internacional.

\section{(c) (1)}

